\title{
Effects of milk composition, stir-out time, and pressing duration on curd moisture and yield
}

\author{
C. D. Everard, ${ }^{\star} †$ D. J. O’Callaghan, ${ }^{\star 1}$ M. J. Mateo, ${ }^{*} \dagger$ M. Castillo,‡ F. A. Payne,‡ and C. P. O’Donnell† \\ *Teagasc, Food Research Centre, Moorepark, Fermoy, Co. Cork, Ireland \\ †Biosystems Engineering, School of Agriculture, Food Science and Veterinary Medicine, Agriculture and Food Science Centre, Belfield, \\ University College Dublin, Dublin 4, Ireland \\ ‡Department of Biosystems and Agricultural Engineering, University of Kentucky, Lexington 40546-0276
}

\begin{abstract}
A study was undertaken to investigate the effects of milk composition (i.e., protein level and protein:fat ratio), stir-out time, and pressing duration on curd moisture and yield. Milks of varying protein levels and protein:fat ratios were renneted under normal commercial conditions in a pilot-scale cheese vat. During the syneresis phase of cheese making, curd was removed at differing times, and curd moisture and yield were monitored over a 22 -h pressing period. Curd moisture after pressing decreased with longer stir-out time and pressing duration, and an interactive effect was observed of stir-out time and pressing duration on curd moisture and yield. Milk total solids were shown to affect curd moisture after pressing, which has implications for milk standardization; that is, it indicates a need to standardize on a milk solids basis as well as on a protein:fat basis. In this study, a decreased protein:fat ratio was associated with increased total solids in milk and resulted in decreased curd moisture and increased curd yield after pressing. The variation in total solids of the milk explains the apparent contradiction between decreased curd moisture and increased curd yield. This study points to a role for process analytic technology in minimizing variation in cheese characteristics through better control of cheesemilk composition, in-vat process monitoring (coagulation and syneresis), and post-vat moisture reduction (curd pressing). Increased control of curd composition at draining would facilitate increased control of the final cheese grade and quality.
\end{abstract}

Key words: syneresis, stir-out time, pressing, curd moisture and yield

\section{INTRODUCTION}

Final cheese moisture is affected by many cheeseprocessing conditions such as coagulation time, curd

Received June 29, 2010.

Accepted February 24, 2011.

${ }^{1}$ Corresponding author: donal.ocallaghan@teagasc.ie particle size, stirring, cooking temperature, and ex-vat curd handling (e.g., dry stirring, cheddaring, salting, duration between salting and pressing, and ripening conditions; Gilles, 1976; Johnston, 2000). Moisture content of cheese after pressing has important implications for the theoretical calculation of salt absorption during the subsequent salting phase, and on water displacement and the loss of weight that accompany it (Geurts, 1978). Understanding the factors that determine cheese moisture content after pressing is essential for control of moisture, salt, and ripening. Control of cheese moisture is paramount to maximizing yield and profitability (Jimenez-Marqueza et al., 2005).

Milk composition is the most important factor affecting cheese yields, of which approximately $93 \%$ of the DM is protein and fat. Fenelon and Guinee (1999) concluded that when using a seasonal milk supply with varying composition it is important to standardize milk to fixed casein:fat ratio. They listed stage of lactation, plane of nutrition, differences in somatic cell counts, health status of cow, duration of cold storage, and efficiency of standardization practices as causes of variation in milk composition. Guinee et al. (2007) reported that, for the Irish cheese industry between 2001 and 2003 , the protein:fat ratio of milk for manufacture of Cheddar cheese varied from 0.84 to 1.02 , with protein varying from 3.0 to $3.6 \%$ (wt/wt) and fat from 3.3 to $4.2 \%$. This variation is due to natural, seasonal-induced variations in levels and relative proportions of fat, protein, casein, and lactose (Banks et al., 1981; Bruhn and Franke, 1991; O'Brien et al., 1999). Guinee et al. (2007) concluded that variations in the protein:fat ratio of cheese milk with a fixed protein level would affect manufacturing efficiency, composition, and quality of Cheddar cheese, and that relatively little published research exists on this topic. Their study showed that protein:fat ratios of cheese milk in the range of 0.70 to 1.15 had marked implications, not only for cheese composition, but also for cheese yield and the percentage recoveries of milk fat and water to cheese.

It is widely known that insoluble $\mathrm{Ca}$ is solubilized in milk with acidification (Dalgleish and Law, 1989). This 
results in a reduction in cross-linking within casein micelles, leading to weaker, more flexible rennet gels and consequential effects on the textural properties of the final cheese (Choi et al., 2004). Higher levels of total Ca in cheese tend to give firmer and less meltable cheeses than those with low Ca concentration (Lucey and Fox, 1993; Guinee et al., 2002; Joshi et al., 2004).

Walstra (2004) reported on the syneresis of curd throughout cheese manufacture, where curd pressing, typically at 10 to $100 \mathrm{kPa}$, leads to a coherent mass of curd. In some cheeses, the outer layer of curd grains fuse together, forming a rind that reduces further expression of whey. The formation of a rind is greatly assisted by rapid moisture removal from this outer layer, assisted by application of cheesecloth. Lower moisture content before pressing results in lower moisture expression during pressing. Initial moisture content before pressing has important implications for the curd moisture postpressing because of the formation of a closed rind at an earlier stage or of a greater rind thickness (Walstra, 2004).

Geurts (1978) studied the distribution of moisture in unsalted cheese. He concluded that temperature distribution plays a role, with moisture moving away from areas of high temperature or areas of high pressure (e.g., the bottom of the cheese loaf). After a certain period of pressing, the fusion of the curd grains becomes complete and the decreased curd permeability impedes further moisture movement (Luyten, 1988). Reinbold and Ernstrom (1988) showed that moisture control in the vat reduces moisture variation in large blocks of Cheddar cheese.

Dejmek and Walstra (2004) showed that external pressure on the curd influences the amount of syneresis. Pressing causes the greatest disruption of milk fat globules. During pressing, fat globules can coalesce whereas free fat and fat globule membrane material can be released (Lopez et al., 2007). These authors studied Emmental cheese microstructure after pressing, by using confocal laser scanning microscopy, and reported that fat globules became embedded in cheese cavities and in the protein matrix and that these fat globules may limit casein aggregation and curd formation as well as curd syneresis by blocking the flow of whey through the cavities. They showed that free fat is susceptible to oiling off during pressing, leading to small fat losses during pressing; that is, whey expelled had a fat content of $0.5 \mathrm{~g} / \mathrm{kg}$ in Emmental cheese after $4 \mathrm{~h}$ of pressing at 0.4 $\mathrm{kPa}$ at a room temperature of $24^{\circ} \mathrm{C}$.

The objective of this study was to investigate the effects of milk composition (i.e., protein levels and protein:fat ratios), stir-out time (i.e., different periods in-vat post-cutting), and pressing duration on curd moisture and yield.
Table 1. Experimental treatments showing milk protein levels $\left(P_{\mathrm{M}}\right)$, protein:fat ratios $\left(P F_{\mathrm{M}}\right)$, milk fat $\left(F_{\mathrm{M}}\right)$, and total solids $\left(T S_{\mathrm{M}}\right)$ in the cheesemilk formulations

\begin{tabular}{lcccc}
\hline Treatment $^{1}$ & $P_{\mathrm{M}}, \%$ & $P F_{\mathrm{M}}$ & $F_{\mathrm{M}}, \%$ & $T S_{\mathrm{M}}, \%$ \\
\hline a1 & 3.3 & 3.33 & 0.99 & 9.0 \\
a2 & 3.3 & 1.43 & 2.31 & 10.3 \\
a3 & 3.3 & 0.91 & 3.63 & 11.6 \\
b1 & 3.7 & 3.33 & 1.11 & 10.1 \\
b2 & 3.7 & 1.43 & 2.59 & 11.6 \\
b3 & 3.7 & 0.91 & 4.07 & 13.0 \\
\hline
\end{tabular}

${ }^{1} \mathrm{a}$ and $\mathrm{b}$ represent the different $P_{\mathrm{M}}$ levels, and 1,2 , and 3 represent the $3 P F_{\mathrm{M}}$ levels.

\section{MATERIALS AND METHODS}

\section{Experimental Design}

Curd protein and fat contents were varied by coagulating milk that was formulated with 2 experimental factors: milk protein level $\left(\boldsymbol{P}_{\mathbf{M}}\right)$ and protein:fat ratio $\left(\boldsymbol{P} \boldsymbol{F}_{\mathrm{M}}\right.$; Table 1). Three randomized factorial replicates were used in this study. Two $P_{\mathrm{M}}$ levels, 3.3 and $3.7 \%$, and $3 P F_{\mathrm{M}}$ ratios, $3.33,1.43$, and 0.91 , were studied in triplicate, giving a total of 18 trials. Curd was drained periodically during syneresis, at $15,35,55$, and $75 \mathrm{~min}$ after cutting time $\left(\boldsymbol{t}_{\text {cut }}\right)$. A pressure of approximately $23 \mathrm{kPa}$ was applied to $80 \mathrm{~g}$ of curd over a 22 -h period to simulate the pressing phase during cheesemaking.

\section{Milk Preparation and Gel Formation}

Milk was recombined in an 11-L cheese vat (Pierre Guerin Technologies, Mauze, France), as described in Everard et al. (2008), from low-heat skim milk powder (Teagasc, Co. Cork, Ireland), distilled water, and cream (Dairygold, Co. Cork, Ireland) at $42 \pm 0.1^{\circ} \mathrm{C}$ while being stirred at $44 \mathrm{rpm}$. Temperature was controlled by a water bath (model Y28 with controller type VFP, Grant Instruments Ltd., Cambridge, UK) connected to a heating jacket on the vat. Milk was formulated to target composition using least squares optimization by means of the Solver tool in Microsoft Excel (v. 10; Microsoft Corp., Redmond, WA). The recombined milk was then cooled to approximately $8^{\circ} \mathrm{C}$ and stirred constantly at $10 \mathrm{rpm}$ overnight.

A fixed profile of coagulation temperature, milk $\mathrm{pH}$, rennet, calcium chloride concentration, cutting program, and stirring speeds was employed. On the day of curd manufacture, calcium chloride $\left(\mathrm{CaCl}_{2} \cdot 2 \mathrm{H}_{2} \mathrm{O}\right)$ was added to the milk $(2.04 \mathrm{mM})$ and $\mathrm{pH}$ was adjusted to 6.7 using $\mathrm{HCl}(1 M)$ at $20 \pm 0.1^{\circ} \mathrm{C}$. The milk was then heated to $32 \pm 0.1^{\circ} \mathrm{C}$ and allowed to equilibrate; then, $100 \%$ recombinant chymosin (Chy-Max Extra, EC 3.4.23.4, isozyme B, 600 international milk clotting units/mL; Chr Hansen Ireland Ltd., Cork, Ireland) was 


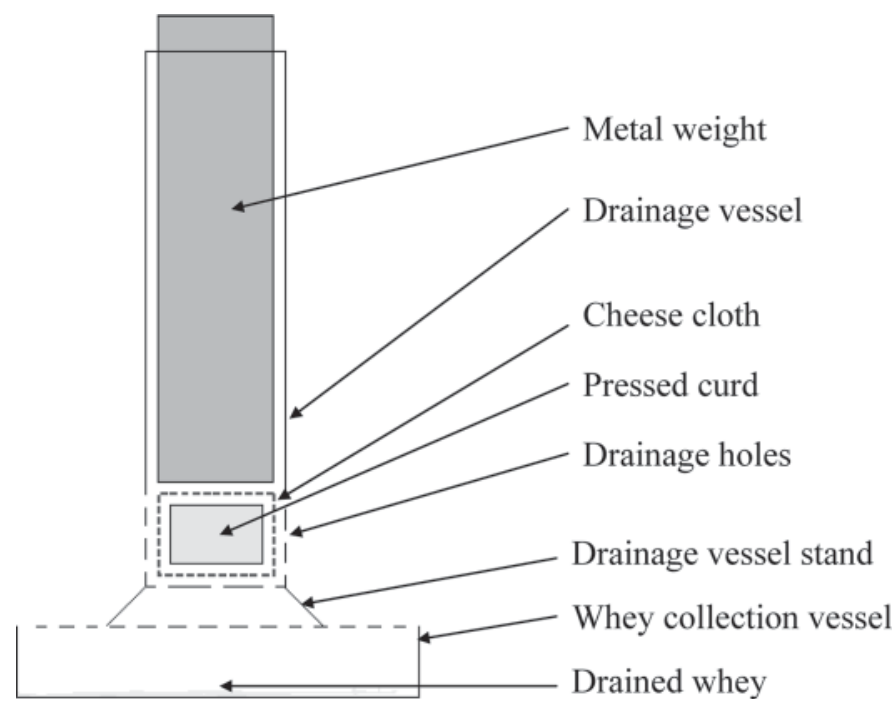

Figure 1. Schematic of cheese curd pressing apparatus used in this study.

added to the milk ( $0.18 \mathrm{~g}$ of chymosin $/ \mathrm{kg}$ of milk at $10 \%$ dilution in distilled water) in the vat while being stirred constantly at $31 \mathrm{rpm}$. Stirring was stopped after 3 min and stirrers were replaced with cutting blades.

\section{Rheological Determination of Cutting Time and Cutting Procedure}

After stirring the rennet homogeneously into the milk, a 20-mL sample of milk was removed immediately from the vat and placed in a small amplitude oscillatory rheometer (AR 2000 EX Rheometer, TA Instruments, Crawley, UK), which was prewarmed to the renneting temperature, $32 \pm 0.1^{\circ} \mathrm{C}$, to determine $t_{\text {cut }}$. The rheometer geometry consisted of a cylindrical bob and cup used in oscillation mode at a shear strain of 0.01 and a frequency of $1 \mathrm{~Hz}$, within the linear viscoelastic region (strain $<0.03)$ reported for rennet milk gels (Mishra et al., 2005). The milk coagulum was cut when the elastic modulus $\left(\mathrm{G}^{\prime}\right)$ reached $35 \mathrm{~Pa}$. Cutting was carried out using a twin set of cutting blades. The moment of initiating gel cutting (i.e., $t_{\text {cut }}$ ) was taken as the reference time $(t=0)$ for all subsequent syneresisrelated measurements. The cutting program consisted of 3 cutting and rest cycles of 1 min duration (Johnston et al., 1998; Everard et al., 2008). The curd was cut at $10 \mathrm{rpm}$ for $40 \mathrm{~s}$, allowed to rest for $20 \mathrm{~s}$, cut at $22 \mathrm{rpm}$ for $40 \mathrm{~s}$, allowed to rest for $20 \mathrm{~s}$, and finally cut again at $22 \mathrm{rpm}$ for $40 \mathrm{~s}$ and allowed to rest again for $20 \mathrm{~s}$.

After gel cutting, the cutting blades were replaced by the stirrers; stirring (at $16 \mathrm{rpm}$ ) commenced at $t=4$ min and continued over the course of syneresis.

\section{Curd Drainage and Pressing}

Quantities of curd-whey mixture $(\sim 270 \mathrm{~mL})$ were removed from the vat for analysis, using a specially designed on-line sampler, at $15,35,55$, and $75 \mathrm{~min}$. Upon removal from the vat, whey was immediately drained from the curd, and the yield and moisture of curd were determined as outlined by Everard et al. (2008). Curd $(\sim 80 \mathrm{~g})$ was accurately weighed onto cheesecloth in a 100-mL beaker, and the curd and cheesecloth were transferred into cylindrical drainage vessels so that the curd loaf surface would be covered by cheesecloth during pressing (Figure 1$)$. A cylindrical weight $(\sim 4.5 \mathrm{~kg})$ was placed on top of the curd and cheesecloth, so that the curd loaf was formed into a cylindrical shape under a pressure of approximately $23 \mathrm{kPa}$ (Figure 1). Drainage vessels were set up to allow whey to flow easily away from the curd during pressing (Figure 1).

\section{Measurements of Curd Properties During Syneresis and Pressing}

Samples of approximately $3 \mathrm{~g}$ of curd were accurately weighed immediately after draining into preweighed aluminum dishes for determination of curd moisture $\left(\boldsymbol{M}_{\mathrm{C}}\right)$, by drying in triplicate in a convection oven at $102^{\circ} \mathrm{C}$ for $16 \mathrm{~h}$ (Everard et al., 2008). Whey fat was measured using the Rose-Gottlieb method (IDF, 1987) and whey protein was determined by the Kjeldahl method (AOAC, 1984). Curd fat $\left(\boldsymbol{F}_{\mathbf{C}}\right)$ and protein $\left(\boldsymbol{P}_{\mathbf{C}}\right)$ were calculated by difference.

The drainage apparatus was weighed after pressing periods of 3, 5, and $22 \mathrm{~h}$. Curd yields $\left(\boldsymbol{Y}_{\mathbf{C}}\right)$ from cheese milk were calculated for each period and denoted $Y_{\mathrm{C} 3}$, $Y_{\mathrm{C} 5}$, and $Y_{\mathrm{C} 22}$, respectively.

After pressing for $22 \mathrm{~h}$, the moisture content of the pressed curd $\left(M_{\mathrm{C} 22}\right)$ was determined by grating the curd loaf and drying the grated curd as for $M_{\mathrm{C}}$ determination.

\section{Statistical Analysis}

Analysis of variance was carried out by using the Proc Mixed procedure in SAS 9.1 (SAS Institute Inc., Cary, NC) to determine the effects of the $P_{\mathrm{M}}, P F_{\mathrm{M}}$, stir-out time $(\boldsymbol{t} \boldsymbol{s})$, and pressing duration $(\boldsymbol{t} \boldsymbol{p})$ on curd moisture and yield values.

\section{RESULTS AND DISCUSSION}

As expected, $M_{\mathrm{C}}$ decreased significantly with increased stir-out time; that is, time in the cheese vat post-cutting (Table 2 and Figure 2). This effect was approximately logarithmic. 


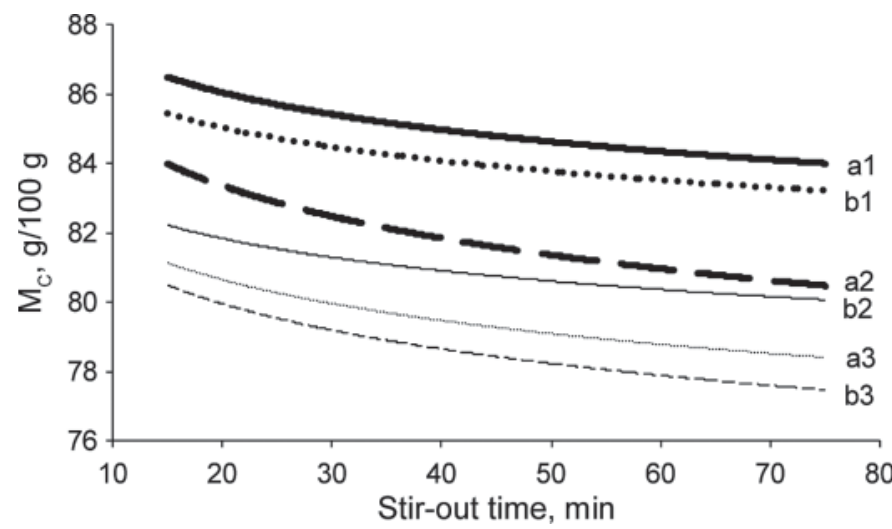

Figure 2. The effect of stir-out time $(t s)$ on curd moisture at draining $\left(M_{\mathrm{C}}\right)$ according to cheesemilk formulation. Shown are logarithmic type trendlines of the data: a1 $\left(\mathrm{R}^{2}=0.85\right)$, a2 $\left(\mathrm{R}^{2}=0.86\right)$, a3 $\left(\mathrm{R}^{2}=\right.$ $0.87), \mathrm{b} 1\left(\mathrm{R}^{2}=0.81\right), \mathrm{b} 2\left(\mathrm{R}^{2}=0.72\right)$, and $\mathrm{b} 3\left(\mathrm{R}^{2}=0.95\right) ;$ see Table 1 for treatment designations.

The composition of cheesemilk, as influenced by formulation $\left(P_{\mathrm{M}}\right.$ and $\left.P F_{\mathrm{M}}\right)$, also influenced $M_{\mathrm{C}}$ (Table 2). This was related to protein and fat levels, which varied with protein and fat levels of the milk; that is, higher total solids in the milk resulted in lower water content in the coagulum and produced lower moisture content in the curd at draining (Figure 2). This has relevance for cheese manufacture, as it demonstrates that milk standardization can facilitate curd consistency at draining, provided that milk composition (protein and fat levels and not merely protein:fat ratio, but also total solids) can be fixed. Guinee et al. (2006) reported a significant decrease in cheese moisture with increasing milk protein and fat levels (increasing milk protein from 3.3 to 3.6 or $4.0 \%$, wt/wt) for Cheddar cheese. The study also concluded no significant effects on cheese moisture due to method of protein standardization (i.e., using phosphocasein, milk protein concentrate, or ultrafiltered milk retentate). A significant increase in recovery of fat and protein in cheese was observed with milk protein level. Studies have shown that simultaneously increasing milk protein and fat levels (i.e., increasing milk protein in the range 3.0 to $4.5 \%$, wt/wt, at a constant fat to protein ratio) resulted in linear increases in actual and moisture-adjusted Cheddar cheese yields (Fenelon and Guinee, 1999).

Curd moisture decreased with tp as expected (Table 2 ), on an approximately logarithmic basis (i.e., the effect of pressing was proportional to the logarithm of time of pressing; Figure 3). Stir-out time also affected curd yield after pressing, and an interactive effect was observed of stir-out time $\times$ pressing duration on curd moisture and curd yield after pressing (Table 2). This implies that control of curd moisture at draining is a crucial element in achieving consistent control over cheese moisture.

Interestingly, the effect of milk composition on curd moisture at draining was also reflected after pressing (Figure 4); that is, formulation affected $M_{\mathrm{C}}$, with curd moisture (before and after pressing) increasing as $P F_{\mathrm{M}}$ increased (Table 2), and this in turn had a clear effect on curd moisture after pressing (Figure 3). Similarly, curd yield after pressing $\left(Y_{\mathrm{C} 3}, Y_{\mathrm{C} 5}\right.$, and $\left.Y_{\mathrm{C} 22}\right)$ decreased with increasing $M_{\mathrm{C}}$ (Table 3 and Figure 5).

Simultaneous with decreases in $M_{\mathrm{C}}$ associated with lower $P F_{\mathrm{M}}, Y_{\mathrm{C} 22}$ was found to increase (Table 3). The contrasting effects of decreased moisture and increased curd yield, an apparent contradiction, require some further elucidation. To discern the related effects of composition, stir-out time, and duration of pressing, one must take into account 2 dimensions of composition within the experimental treatments; namely (1) increases in fat level at constant total solids (with reduction in protein level) and (2) increases in protein levels in the milk at constant fat level (with increases in total solids). In case (1), increasing fat level at constant total solids was found to decrease $M_{\mathrm{C}}$ and after pressing (e.g., $M_{\mathrm{C} 22}$; Table 3 ). The effect on curd yield after pressing depended on the initial solids level in the milk: at low solids level (from b1 to a2), a positive effect was found on curd yield; at high solids level (from b2 to a3), the effect was not significant (Figure 5). In case (2), although ANOVA on the experimental variables showed

Table 2. Analysis of variance and $F$ statistic showing the effects of milk protein level $\left(P_{\mathrm{M}}\right)$, protein:fat ratio $\left(P F_{\mathrm{M}}\right)$, stir-out time $(t s)$, and pressing duration $(t p)$ on moisture and curd yield values, along with their interactive effects, using mixed model analysis

\begin{tabular}{|c|c|c|c|c|c|c|c|c|c|c|}
\hline Item $^{1}$ & $P_{\mathrm{M}}$ & $P F_{\mathrm{M}}$ & ts & $t p$ & $\begin{array}{c}P_{\mathrm{M}} \\
\times P F_{\mathrm{M}}\end{array}$ & $\begin{array}{l}P_{\mathrm{M}} \\
\times t s\end{array}$ & $\begin{array}{l}P F_{\mathrm{M}} \\
\times t s\end{array}$ & $\begin{array}{c}P_{\mathrm{M}} \\
\times t p\end{array}$ & $\begin{array}{l}P F_{\mathrm{M}} \\
\times t p\end{array}$ & $\begin{array}{c}t s \\
\times t p\end{array}$ \\
\hline df & 1 & 2 & 3 & 2 & 2 & 3 & 6 & 2 & 4 & 6 \\
\hline$M_{\mathrm{C}}$ & $29.96^{* * *}$ & $376.0^{* * *}$ & $145.51^{* * *}$ & - & $0.06^{\mathrm{NS}}$ & $1.29^{\mathrm{NS}}$ & $0.91^{\mathrm{NS}}$ & - & - & - \\
\hline$Y_{\mathrm{C}}$ & $3.55^{\mathrm{NS}}$ & $9.73^{* *}$ & $73.03^{* * *}$ & $1,470 * * *$ & $0.16^{\mathrm{NS}}$ & $0.74^{\mathrm{NS}}$ & $1.50^{\mathrm{NS}}$ & $0.36^{\mathrm{NS}}$ & $1.91^{\mathrm{NS}}$ & $4.42^{* * *}$ \\
\hline$M_{\mathrm{CP}}$ & $0.29^{\mathrm{NS}}$ & $276.9^{* * *}$ & $95.26^{* * *}$ & $953.7^{* * *}$ & $0.56^{\mathrm{NS}}$ & $0.29^{\mathrm{NS}}$ & $2.79^{*}$ & $1.34^{\mathrm{NS}}$ & $4.48^{* *}$ & $12.44^{* * *}$ \\
\hline
\end{tabular}

\footnotetext{
${ }^{1} M_{\mathrm{C}}=$ curd moisture content at draining; $M_{\mathrm{C} 22}=$ curd moisture after $22 \mathrm{~h}$ of pressing; $Y_{\mathrm{C}}=$ curd yield from milk over the stir-out period; $M_{\mathrm{CP}}$ $=$ curd moisture during pressing; $Y_{\mathrm{C}}$ and $M_{\mathrm{CP}}$ represent response values after any duration of pressing; that is, 3,5 , or $22 \mathrm{~h}$.

${ }^{*} P<0.05$; ${ }^{* *} P<0.01$; *** $P<0.001$.
} 


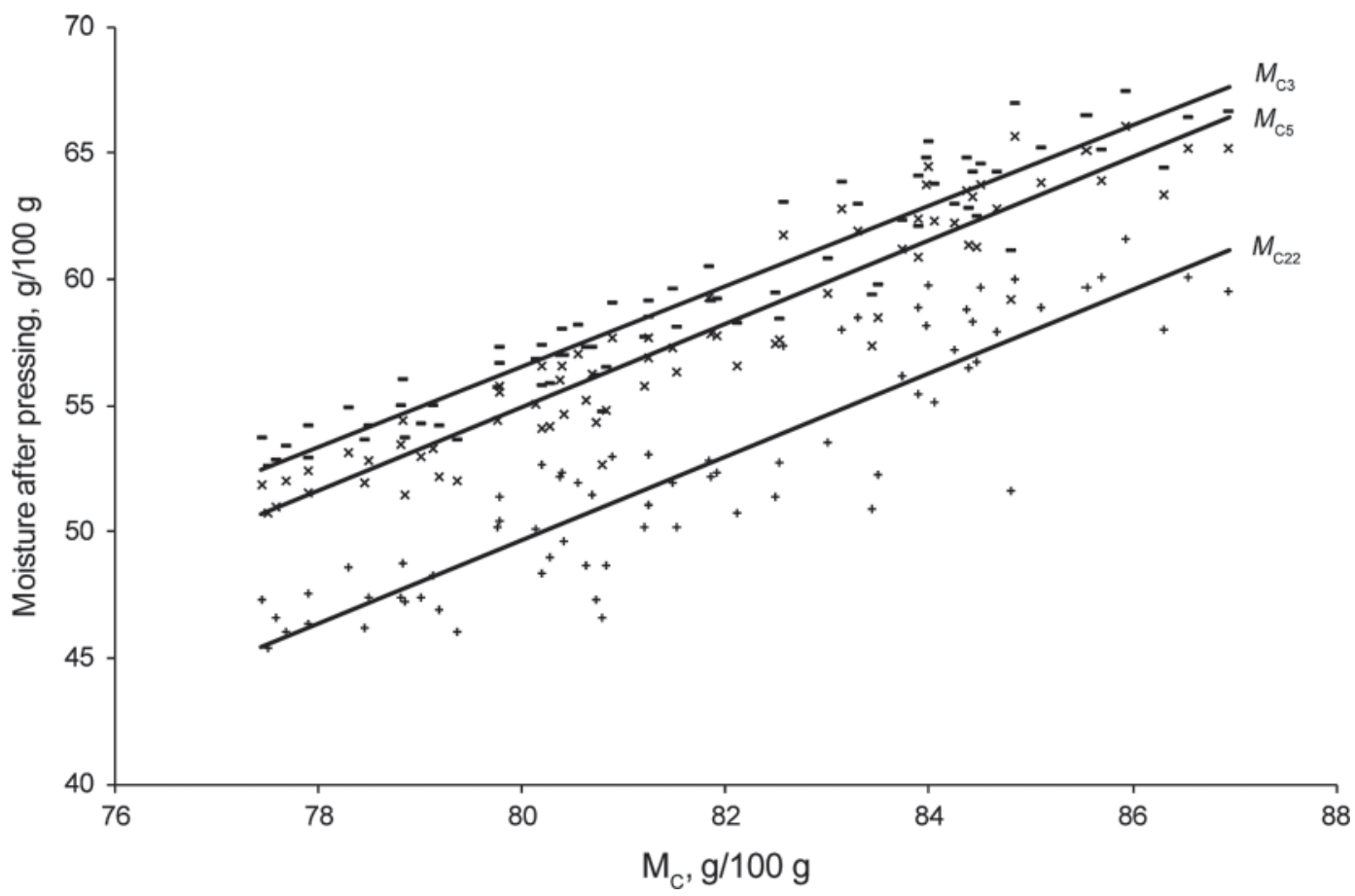

Figure 3. Trend for moisture after pressing for $3 \mathrm{~h}\left(M_{\mathrm{C} 3},-; \mathrm{R}^{2}=0.91\right), 5 \mathrm{~h}\left(M_{\mathrm{C} 5}, \times ; \mathrm{R}^{2}=0.90\right)$, and $22 \mathrm{~h}\left(M_{\mathrm{C} 22},+; \mathrm{R}^{2}=0.82\right)$ versus curd moisture at draining $\left(M_{\mathrm{C}}\right)$, showing the decrease in moisture after pressing with pressing duration $(t p)$.

that protein level in milk at a constant fat level had a significant overall effect on curd moisture at draining, the effect at the level of individual formulations was not significant and it did not show a significant effect on moisture of pressed curd (Table 3 and Figure 5).
Protein level in milk at constant fat level did not have an overall effect on curd yield after pressing, but an effect was observed for some milk formulations $(\mathrm{a} 2$, b2), with increasing protein level resulting in a significant increase in final yield, where $P F_{\mathrm{M}}=1.43$ (Table 3 ).

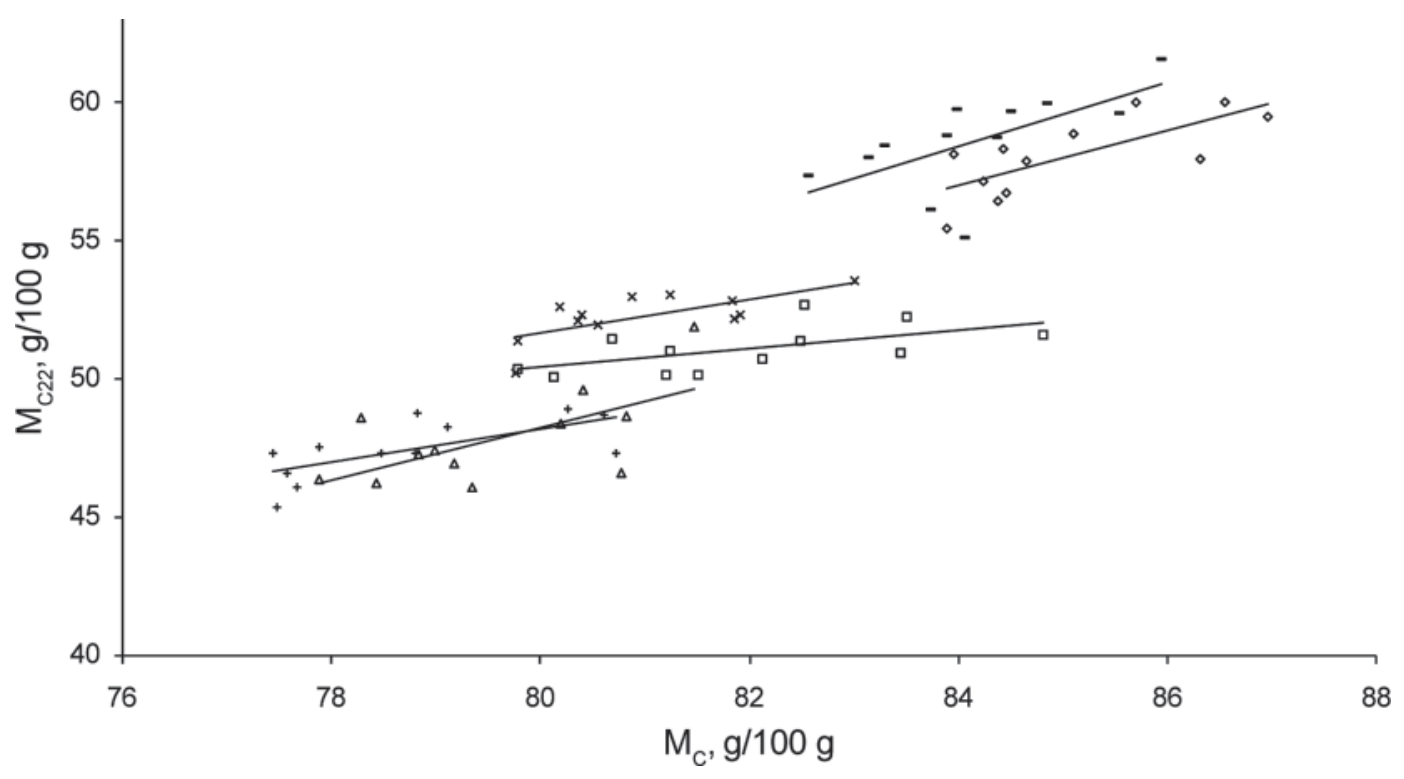

Figure 4. Influence of milk formulation and curd moisture at draining $\left(M_{\mathrm{C}}\right)$ on curd moisture after pressing for $22 \mathrm{~h}$, $M_{\mathrm{C} 22}$, according to cheesemilk formulation: a1 $(\diamond)$, a $2(\square)$, a3 $(\Delta)$, b1 $(-)$, b2 $(\times)$, and b3 $(+)$; see Table 1 for treatment designations. 


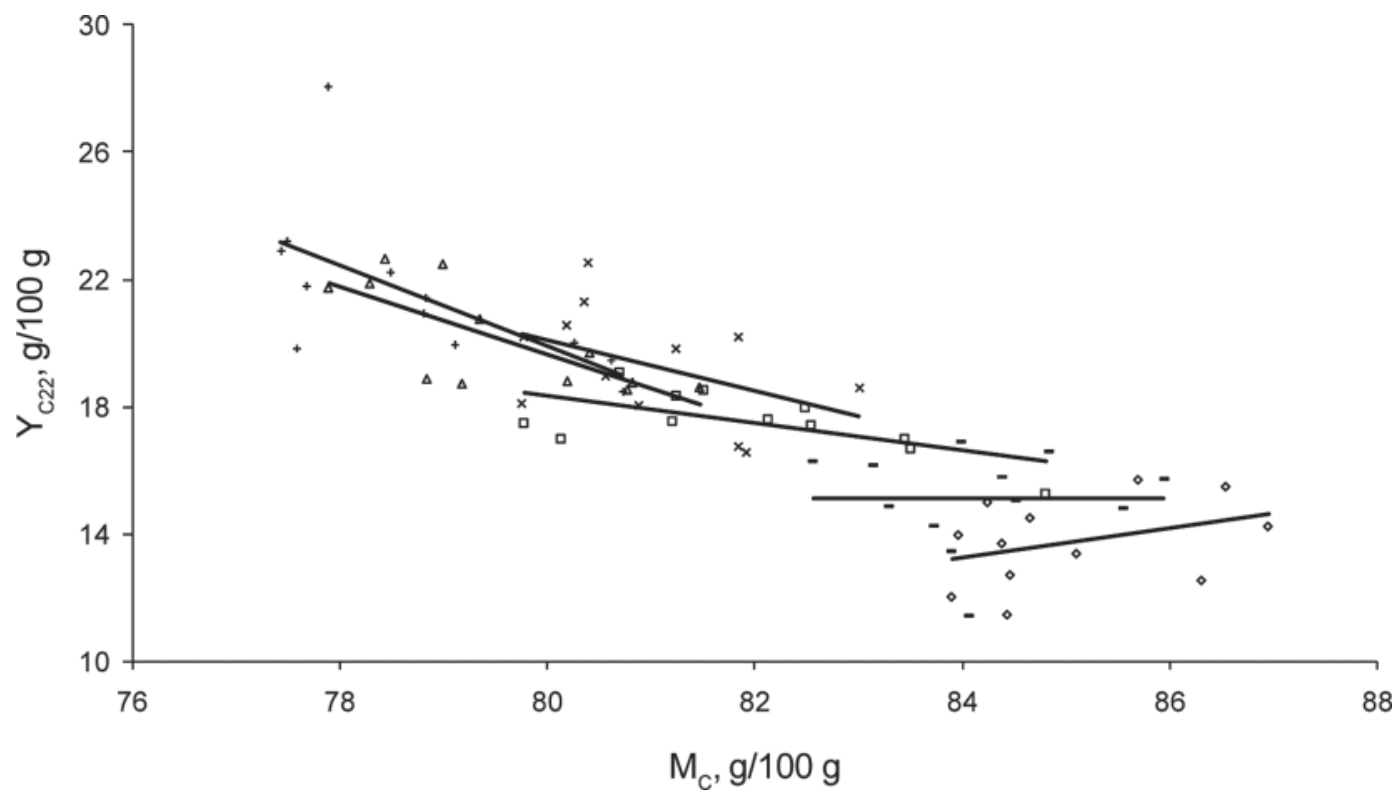

Figure 5. Effects milk formulation and curd moisture at draining $\left(M_{\mathrm{C}}\right)$ on curd yield after pressing for $22 \mathrm{~h}\left(Y_{\mathrm{C} 22}\right)$ according to cheesemilk formulation: a1 $(\diamond)$, a2 $(\square)$, a3 $(\Delta)$, b1 $(-)$, b2 $(\times)$, and b3 $(+)$; see Table 1 for treatment designations.

\section{CONCLUSIONS}

This study showed an interactive effect between stir-out time and pressing duration on curd moisture and yield. It was observed in this study that milk total solids, involving fat or casein, has an effect on curd moisture after pressing, which has implications for milk standardization; that is, showing a need to standardize on a fat and casein basis and not just on a protein:fat basis. Increasing milk fat level at constant total solids was found to decrease curd moisture at draining and after pressing (i.e., moisture in cheese is associated with protein more than with fat). However, protein level in milk did not affect curd yield or moisture after pressing; this confirms the importance of moisture control at drainage. Decreased protein:fat ratio in this study was associated with increased total solids in milk and resulted in decreased curd moisture and increased curd

Table 3. Average values for curd moisture at draining $\left(M_{\mathrm{C}}\right)$ and after pressing for $22 \mathrm{~h}\left(M_{\mathrm{C} 22}\right)$ and curd yield after pressing $\left(Y_{\mathrm{C} 22}\right)$ according to cheesemilk composition

\begin{tabular}{|c|c|c|c|c|c|}
\hline \multirow{2}{*}{$\begin{array}{l}\text { Design } \\
\text { code }\end{array}$} & \multicolumn{2}{|c|}{ Case $^{1}$} & \multicolumn{3}{|c|}{ Curd moisture and yield } \\
\hline & (1) & $(2)$ & $M_{\mathrm{C}}$ & $M_{\mathrm{C} 22}$ & $Y_{\mathrm{C} 22}$ \\
\hline a1 & & & $85.1^{\mathrm{a}}$ & $58.1^{\mathrm{a}}$ & $13.8^{\mathrm{a}}$ \\
\hline $\mathrm{a} 2$ & $\Delta$ & 9 & $82.0^{\mathrm{b}}$ & $51.1^{\mathrm{b}}$ & $17.5^{\mathrm{b}}$ \\
\hline a3 & & 8 & $79.6^{\mathrm{c}}$ & $47.8^{\mathrm{c}}$ & $20.1^{\mathrm{cc}}$ \\
\hline b1 & 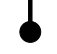 & & $84.2^{\mathrm{a}}$ & $58.6^{\mathrm{a}}$ & $15.1^{\mathrm{a}}$ \\
\hline $\mathrm{b} 2$ & & $\downarrow$ & $81.0^{\mathrm{b}}$ & $52.3^{\mathrm{b}}$ & $19.3^{\mathrm{d}}$ \\
\hline b3 & & $\downarrow$ & $78.7^{\mathrm{c}}$ & $47.5^{\mathrm{c}}$ & $21.5^{\mathrm{c}}$ \\
\hline
\end{tabular}

$\overline{\mathrm{a}-\mathrm{d}}$ Values with common superscripts within a column are not significantly different.

${ }^{1}$ Case $(1)=$ increase in fat level in milk at constant total solids, b1 to a2; b2 to a3; case $(2)=$ increase in protein level in milk at constant fat level, a1 to b1, a2 to b2, a3 to b3; see Table 1 for treatment designations. 
yield after pressing. It is apparent that the main factor was the variation in total solids of the milk, which explains the apparent contradiction between decreased curd moisture and increased curd yield. This study points to a role for process analytical technology in minimizing variation in cheese characteristics through better control of cheese milk composition, in-vat process monitoring (coagulation and syneresis), and postvat moisture reduction (curd pressing).

\section{ACKNOWLEDGMENTS}

Funding for this research was provided under the National Development Plan, through the Food Institutional Research Measure (FIRM), administered by the Irish Department of Agriculture, Fisheries \& Food.

\section{REFERENCES}

AOAC. 1984. Page 1141 in Official Methods of Analysis. Association of Official Analytical Chemists, Arlington, VA.

Banks, J. M., W. Banks, D. D. Muir, and A. G. Wilson. 1981. Cheese yield: Composition does matter. Dairy Indust. Int. 46:15-22.

Bruhn, J. C., and A. A. Franke. 1991. Raw milk composition and cheese yields in California: 1987 and 1998. J. Dairy Sci. 74:11081114 .

Choi, J., D. S. Horne, M. E. Johnson, and J. A. Lucey. 2004. Effects of insoluble calcium phosphate on cheese functionality. J. Dairy Sci. 87(Suppl. 1):231. (Abstr.)

Dalgleish, D. G., and A. J. R. Law. 1989. pH-induced dissociation of bovine casein micelles. II. Mineral solubilization and its relation to casein release. J. Dairy Res. 56:727-735.

Dejmek, P., and P. Walstra. 2004. The syneresis of rennet-coagulated curd. Pages 71-103 in Cheese: Chemistry, Physics and Microbiology. Vol. 1: General aspects. 3rd ed. P. Fox, P. McSweeney, T. Cogan, and T. Guinee, ed. Elsevier, Amsterdam, the Netherlands.

Everard, C. D., D. J. O'Callaghan, M. J. Mateo, C. P. O'Donnell, M. Castillo, and F. A. Payne. 2008. Effects of cutting intensity and stirring speed on syneresis and curd losses during cheese manufacture. J. Dairy Sci. 91:2575-2582.

Fenelon, M. A., and T. P. Guinee. 1999. The effect of milk fat on Cheddar cheese yield and its prediction, using modifications of the Van Slyke cheese yield formula. J. Dairy Sci. 82:2287-2299.

Geurts, T. J. 1978. Some factors which affect the moisture content of cheese before salting. Neth. Milk Dairy J. 32:112-124.
Gilles, J. 1976. Moisture control in Cheddar cheese. N.Z. J. Dairy Sci. Technol. 11:71-72.

Guinee, T. P., E. P. Feeney, M. A. E. Auty, and P. F. Fox. 2002. Effect of $\mathrm{pH}$ and calcium concentration on some textural and functional properties of Mozzarella cheese. J. Dairy Sci. 85:1655-1669.

Guinee, T. P., E. O. Mulholland, J. Kelly, and D. J. O'Callaghan. 2007. Effect of protein-to-fat ratio of milk on the composition, manufacturing efficiency, and yield of Cheddar cheese. J. Dairy Sci. 90:110-123.

Guinee, T. P., B. T. O'Kennedy, and P. M. Kelly. 2006. Effect of milk protein standardization using different methods on the composition and yields of Cheddar cheese. J. Dairy Sci. 89:468-482.

International Dairy Federation. 1987. Milk. Determination of fat content-Röse Gottlieb gravimetric method. FIL-IDF standard 1C. IDF, Brussels, Belgium.

Jimenez-Marqueza, S. A., J. Thibaultb, and C. Lacroixc. 2005. Prediction of moisture in cheese of commercial production using neural networks. Int. Dairy J. 15:1156-1174.

Johnston, K. A. 2000. Control and recovery of fat and protein losses. Pages 40-48 in Practical Guide for Control of Cheese Yield. International Dairy Federation, Brussels, Belgium.

Johnston, K. A., M. S. Luckman, H. G. Lilley, and B. M. Smale. 1998. Effect of various cutting and stirring conditions on curd particle size and losses of fat to the whey during Cheddar cheese manufacture in Ost vats. Int. Dairy J. 8:281-288.

Joshi, N. S., K. Muthukumarappan, and R. I. Dave. 2004. Effect of calcium on microstructure and meltability of part skim Mozzarella cheese. J. Dairy Sci. 87:1975-1985.

Lopez, C., B. Camier, and J.-Y. Gassi. 2007. Development of the milk fat microstructure during the manufacture and ripening of Emmental cheese observed by confocal laser scanning microscopy. Int. Dairy J. 17:235-247.

Lucey, J. A., and P. F. Fox. 1993. Importance of calcium and phosphate in cheese manufacture: A review. J. Dairy Sci. 76:1714-1724.

Luyten, H. 1988. The rheological and fracture properties of Gouda cheese. PhD Thesis. Wageningen Agricultural University, Wageningen, the Netherlands.

Mishra, R., S. Govindasamy-Lucey, and J. A. Lucey. 2005. Rheological properties of rennet-induced gels during the coagulation and cutting process: Impact of processing conditions. J. Texture Stud. $36: 190-212$

O'Brien, B., R. Mehra, J. F. Connolly, and D. Harrington. 1999. Seasonal variation in the composition of Irish manufacturing and retail milks. 1. Chemical composition and renneting properties. Ir. J. Agric. Food Res. 38:53-64.

Reinbold, R. S., and C. A. Ernstrom. 1988. Effect of nonuniform cooling on moisture, salt, and $\mathrm{pH}$ distribution in 290-kilogram blocks of stirred-curd Cheddar cheese. J. Dairy Sci. 71:1499-1506.

Walstra, P. 2004. The syneresis of curd. Pages 141-191 in Cheese: Chemistry, Physics, and Microbiology. Vol. 1. General Aspects. 2nd ed. P. F. Fox, ed. Chapman and Hall, London, UK. 